\title{
THE PRODUCTION AND BODY COMPOSITION OF KACANG GOAT FED DIFFERENT QUALITY OF DIETS
}

\author{
V. Restitrisnani, A. Purnomoadi and E. Rianto \\ Faculty of Animal and Agricultural Sciences, Diponegoro University, \\ Tembalang Campus, Semarang 50275 - Indonesia \\ Corresponding E-mail: restitrisnani.vita@yahoo.com
}

Received June 25, 2013; Accepted August 19, 2013

\begin{abstract}
ABSTRAK
Sebuah studi eksperimental dilakukan untuk menilai pengaruh kualitas pakan pada produktivitas dan komposisi tubuh dari kambing Kacang. Lima belas ekor kambing Kacang jantan dengan bobot badan 14,28 $\pm 3,36 \mathrm{~kg}(\mathrm{CV}=23,55 \%)$ dibagi menjadi 5 kelompok berdasarkan bobot badan. Desain eksperimen yang digunakan dalam penelitian ini adalah Rancangan Acak Kelompok (RAK) dengan 3 perlakuan kandungan protein dan total nutrien tecerna (total digestible nutrients, TDN) yaitu T1 = pakan dengan protein $9,20 \%$ dan 54,67\% TDN, T2 = ransum dengan protein $11,6 \%$ dan 58,61\% TDN, T3= ransum dengan protein $18,33 \%$ dan $65,23 \%$ TDN). Parameter yang diamati dalam penelitian ini adalah konsumsi bahan kering pakan, konsumsi protein kasar, konsumsi TDN, pertambahan bobot badan dan komposisi tubuh dari kambing Kacang. Hasil penelitian menunjukkan bahwa kualitas pakan perlakuan tidak berpengaruh nyata $(\mathrm{P}>0,05)$ pada konsumsi bahan kering dan komposisi tubuh, tetapi berpengaruh nyata $(\mathrm{P}<0,05)$ pada konsumsi protein, konsumsi TDN dan pertambahan bobot badan. Dari penelitian ini dapat disimpulkan bahwa kualitas pakan yang lebih tinggi menghasilkan produktivitas yang lebih tinggi, tetapi kualitas pakan yang lebih tinggi pada penelitian ini tidak mempengaruhi komposisi tubuh dari kambing Kacang, kecuali pertambahan lemak tubuh (\%).

Kata kunci : kambing Kacang, kualitas pakan, komposisi tubuh, produktivitas
\end{abstract}

\begin{abstract}
An experimental study was carried out to assess the effect of diet quality on productivity and body composition of Kacang goat. Fifteen male Kacang goats weighing $14.28 \pm 3.36 \mathrm{~kg}(\mathrm{CV}=23.55 \%)$ were divided into 5 groups based on body weight. The experimental design used in this study was Randomized Block Design (RBD) with 3 treatments of dietary protein and total digestible (TDN) contents $(\mathrm{T} 1=$ diet with $9.20 \%$ protein and $54.67 \% \mathrm{TDN}$; $\mathrm{T} 2=$ diet with $11.6 \%$ protein and $58.61 \%$ TDN; T3= diet with $18.33 \%$ protein and $65.23 \%$ TDN). Parameters observed were feed intake, dry matter intake, crude protein intake, TDN intake, live weight gain (LWG) and body composition of Kacang goat. The results showed that feed quality did not significantly affect $(\mathrm{P}>0.05)$ dry matter intake and body composition, but significantly affect $(\mathrm{P}<0.05)$ protein intake, TDN intake and LWG. It can be concluded that the higher quality diet resulted in higher productivity, but the higher quality diet was not affect body composition of Kacang goat, except body fat gain (\%).
\end{abstract}

Keywords: Kacang goat, feed quality, body composition, productivity

\section{INTRODUCTION}

Kacang goat is one of the local breeds of goat which is potential to be developed in Indonesia. The population of this goat was $7,325,977$ in 2011 or equal to $41.9 \%$ of the total goat population in Indonesia (Direktorat Jenderal Peternakan and Kesehatan Hewan, 2012). Kacang goat has strong adaptability to coarse environment such as heat stress and low quality feed. Some previous studies reported that the carcass percentage of Kacang goat reach ranged between 41,8 and 46.7\% (Triantini et al., 2002; Usmiati, 2008; Karami et al., 2013). Kacang goat is prolific and 26\% kid mortality (Sumardianto et al., 2013; Gatenby, 1988; Dinas Peternakan Brebes and Balai Pengkajian Teknologi Pertanian Jawa Tengah, 2005).

Feed quality is one of important factors that need to be considered for the development of 
animal farming system. High quality feed is needed to increase animal productivity, since it affects feed intake, growth rate and growth efficiency of animal (Mahgoub et al., 2000). Feed intake affects the body composition of animal (fat) (Owen et al., 1993, Manso et al., 1998). Abdullah et al. (2007) reported that male black goats fed different levels of energy i.e. 10.44, 11.60, and 12.90 MJ ME/ kg DM, resulted in 133, 92 and $100 \mathrm{~g} / \mathrm{d}$ body weight gain, respectively. Similar results were reported by Aregheore (2006) that crossbred of Anglo-Nubian x Fiji local goats fed diet containing energy 17.0, 18.1, 19.1 and $20.0 \mathrm{MJ} / \mathrm{kg} \mathrm{DM}$ and obtained body weight gain $67,81,86$ and $109 \mathrm{~g} / \mathrm{d}$, respectively.

Animal productivity is not only evaluated through body weight gain, but also body composition, because the real value of animal productivity is meat or body protein. Animal body consists of water, protein and fat (Soeparno, 1992). The proportion of these components varies with the quality of diet, growth rate and body weight. Sahlu et al. (1999) reported that carcass of Angora goat fed $14.7 \%$ dietary protein contained $13.5 \%$ protein, $26.5 \%$ fat and $52.8 \%$ water. Other results were reported by Atti et al. (2004) that Tunisian local goats fed different level protein diet $(10,13$ and $16 \%)$ gave $74.3 \%$ to $76 \%$ body water, $22.4 \%$ to $23.4 \%$ body protein and $2.0 \%$ to $4.5 \%$ body fat. Ngwa et al. (2007) observed Boer $\mathrm{x}$ Spanish goat treated with different level feed intake resulted in $14.3 \%$ to $14.7 \%$ body protein, $54 \%$ to $56 \%$ body water, $25 \%$ to $29 \%$ body fat.

The explanation above showed that feed quality was considered related to the body weight gain and body composition of animal. Therefore, the objective this study was to investigate the effect of feed quality on body weight gain and body composition of Kacang goat.

\section{MATERIALS AND METHODS}

\section{Experimental Animal and Diet}

Fifteen male Kacang goats with body weight ranging from 8.77 to $19.87 \mathrm{~kg}$ (average $14.28 \pm$ $3.36 \mathrm{~kg} ; \mathrm{CV}=23.55 \%$ ) were divided into 5 groups of body weight. Each group contained 3 goats. The goats were fed 3 diets of different quality as treatments. The proportion of feedstuffs and the nutritional content of the diets are shown in Table 1.

\section{Experimental Design}

The goats were assigned to a Randomized
Block Design, with 5 groups of body weight $(\mathrm{BW} 1=17.13$ to $19.87 \mathrm{~kg}$; BW2 = 14.98 to 16.71 $\mathrm{kg} ; \mathrm{BW} 3=14.62$ to $14.94 \mathrm{~kg} ; \mathrm{BW} 4=11.71$ to $14.33 \mathrm{~kg} ; \mathrm{BW}=8.77$ to $9.55 \mathrm{~kg}$ ) and 3 treatments $(\mathrm{T} 1=$ feeding with $9.20 \%$ protein and $54.67 \%$ TDN; $\mathrm{T} 2=$ feeding with $11.6 \%$ protein and $58.61 \%$ TDN; T3= feeding with $18.33 \%$ protein and $65.23 \%$ TDN). Each treatment consisted of 5 goats as replicates.

\section{Procedures}

The experiment was conducted in three stages, i.e. adaptation period (6 weeks), preliminary period ( 1 week) and treatment period (10 weeks). The goats were placed in individual cages and fed with three different quality diets. Feed was given based on DM requirement, i.e. $4.5 \%$ of body weight. The feed was offered 4 times a day at 08.00, 13.00, 18.00 and 21.00. The residuals feed were collected and weighed every morning of the following day. Fresh water was provided ad libitum. The goats were weighed every week to determine the amount of feed given in the next week. In the week 0,4 and 8 , and 2 days before goats were slaughtered at the end of experiment, the goats' body composition was measured by urea space technique.

\section{Parameters Measurement}

Parameters observed in this study were dry matter intake (DMI), crude protein (CP) intake, total digestible nutrients (TDN) intake, live weight gain (LWG), feed efficiency and body composition of the goats. Feed intake was determined by subtracting the residual feed to the feed given. TDN was determined by sum up digestible protein, digestible extract ether (multiplying to 2.25), digestible crude fiber and digestible NFE. The feed digestibility was determined by total collection method, which was conducted in the $7^{\text {th }}$ week of experiment. Feces collected were sprayed with $20 \% \mathrm{H} 2 \mathrm{SO} 4$, placed into the plastic bag and stored in $16^{\circ} \mathrm{C}$ cooled room. Feces from 7 days collection was blended, homogenized and sampled for $20 \mathrm{~g}$. The samples feces were then analyzed to determine the chemical composition. Live weight gain was calculated by subtracting the initial body weight to final body weight, divided the duration of observation (day). Feed efficiency was obtained by dividing body weight gain with dry matter intake and multiplied by 100 percent.

Dry matter, $\mathrm{CP}$ and TDN intakes were obtained by subtracting residual feed to feed 
Table 1. Proportion of Feedstuff and Nutritional Content of the Experimental Diet

\begin{tabular}{lrrr}
\hline Feed Ingredients/Nutrients & T1 & T2 & T3 \\
\hline Feed Composition & 7.0 & 8.0 & 9.0 \\
Napier grass & 10.0 & 9.0 & 8.0 \\
Rice Bran & 73.0 & 67.0 & 61.4 \\
Cassava & 10.0 & 16.0 & 22.0 \\
Soybean meal & & & \\
Nutrient Composition (100\% DM) & 87.38 & 87.48 & 87.14 \\
Dry Matter (DM) & 9.20 & 11.67 & 18.33 \\
Crude Protein (CP) & 29.89 & 27.69 & 26.23 \\
Crude Fiber (CF) & 0.34 & 0.57 & 0.57 \\
Extract Ether (EE) & 48.73 & 48.98 & 45.00 \\
Nitrogen Free Extract (NFE) & 54.67 & 58.61 & 65.23 \\
Total Digestible Nutrients ${ }^{*}$ (TDN) & $1: 5.94$ & $1: 5.02$ & $1: 3.56$ \\
Ratio CP/TDN & & \\
\hline
\end{tabular}

given to, multiplied by the nutrient content of feed (DM, CP and TDN). Live weight gain was calculated by subtracting the initial body weight to the final body weight divided by the length of time of observation. The methods for predicting body composition was urea space technique. One day before urea injection, the goats were weighed to measure their body weight and calculate the metabolic body weight $\left(\mathrm{BW}^{0.75}\right)$ to determine the dose of urea injection $(0.65 \mathrm{ml} / \mathrm{kg}$ metabolic body weight). Urea was injected using catheter and flushed with $10 \mathrm{ml} \mathrm{NaCl}$ to ensure all dose of urea entered into the blood. The actual quantity of urea injected was determined by weighing syringes before and after injection. An amount of $10 \mathrm{ml}$ blood sample was collected before and 12 minute after urea injection through jugular vein. The blood sample was centrifuged at $3000 \mathrm{rpm}$ for ten minute to obtain blood plasma for further analysis of urea concentration. Body composition of the goat calculated following the recommendation of Bartle et al. (1983), Panaretto and Till (1963), Rule et al. (1986) and Astuti and Sastradipradja (1999) as the following formulas.

$$
\text { - } \text { Urea Space }=[(\mathrm{V} \times \mathrm{C}) /(\mathrm{DBUN} \times 10 \times \mathrm{LW})]
$$
where:

$\mathrm{V}=$ volume of urea solution that was injected $(\mathrm{ml}) ; \mathrm{C}=$ concentration of urea solution $(\mathrm{mg} / \mathrm{dl})$; $\triangle \mathrm{BUN}=$ change of blood urea nitrogen $(0$ and 12 minutes) $(\mathrm{mg} / 100 \mathrm{ml}) ; \quad \mathrm{US}=$ urea space; $\mathrm{BW}=$ body weight $(\mathrm{kg})$; EBW = empty body weight.

- Body water $(\%) \quad=59.1+0.22 \times$ US (\%) $-0.04 \mathrm{BW}$

- Body water $(\mathrm{kg}) \quad=\{$ body water $(\%) \mathrm{x}$ EBW $(\mathrm{kg}) / 100 \%\}$

- Body protein $(\mathrm{kg}) \quad=0.265 \mathrm{x}$ body water (kg) -0.47

- Body protein $(\%)=100 \mathrm{x}$ (body protein $(\mathrm{kg}) / \mathrm{EBW}$

- Body fat $(\%) \quad=98.0-1.32 \mathrm{x}$ body water $(\%)$

- Body fat $(\mathrm{kg}) \quad=$ \{body fat $(\%) \mathrm{x}$ EBW (kg) $\} / 100 \%$

The changes of body composition were obtained by subtracting the data of 4 th week with prior data of 0 week, or 8th week to 4 th week, as well as 8 th week to 0 , respectively.

\section{Statistical Analyses}

The data observed were analyzed by ANOVA. When there was a significant difference $(\mathrm{P}<0.05)$ among the treatments, the further test by Duncan multiple range test was carried out.

\section{RESULTS AND DISCUSSION}

\section{Feed Intake and Daily Gain}

Data of the effects of different feed quality 
Table 2. The effect of Different Feed Quality on Dry Matter Intake, Protein Intake, TDN Intake and Live Weight Gain

\begin{tabular}{lccc}
\hline \multicolumn{1}{c}{ Parameters } & $\mathrm{T} 1$ & $\mathrm{~T} 2$ & $\mathrm{~T} 3$ \\
\hline DMI (g) & 517.21 & 610.89 & 604.35 \\
Protein intake (g/day) & $48.00^{\mathrm{A}}$ & $71.00^{\mathrm{B}}$ & $111.00^{\mathrm{C}}$ \\
TDN intake (g/day) & $281.62^{\mathrm{a}}$ & $360.08^{\mathrm{b}}$ & $393.81^{\mathrm{b}}$ \\
DM digestibility (\%) & $57.66^{\mathrm{A}}$ & $61.13^{\mathrm{A}}$ & $68.36^{\mathrm{B}}$ \\
Feed Efficiency (\%) & $4.24^{\mathrm{a}}$ & $10.63^{\mathrm{b}}$ & $11.73^{\mathrm{b}}$ \\
LWG (g/day) & $23.46^{\mathrm{A}}$ & $61.86^{\mathrm{B}}$ & $69.41^{\mathrm{B}}$ \\
VFA (mMol) & 36.11 & 39.41 & 38.33 \\
\hline
\end{tabular}

Superscripts with different small letters in the same row indicate significant difference $(\mathrm{P}<0.05)$, superscripts with different capital letters in the same row indicate highly significant differences $(\mathrm{P}<0.01)$

on dry matter intake, protein intake, TDN intake and live weight gain are presented in Table 2. The feed given ( $4.5 \%$ body weight) was consumed by all the goats in all treatments. Differences were found in TDN intake, feed efficiency $(\mathrm{P}<0.05)$, protein intake, DM digestibility and LWG $(\mathrm{P}<0.01)$. Protein intake on $\mathrm{T} 2$ was highly significantly $(\mathrm{P}<0.01)$ higher than $\mathrm{T} 1$, and protein intake on $\mathrm{T} 3$ highly significantly $(\mathrm{P}<0.01)$ higher than T2. While TDN intake on T2 was significantly higher $(\mathrm{P}<0.05)$ than $\mathrm{T} 1$, and TDN intake on T3 was not significantly different $(\mathrm{P}>0.05)$ with T2 (Table 2). The observed differences in TDN and protein intakes were attributed to the content of CP and TDN in diets. This is in accordance with the opinion of Boorman (1980), Martawidjaja et al. (1999) and Atti et al. (2004), that the amount of nutrients consumed by the animal is influenced by the nutrient content of feed given.

Table 2 also shows that an increase in dietary $\mathrm{CP}$ and TDN content increased the DM digestibility, feed efficiency and LWG. This was caused by protein and TDN affected rumen conditions. Most of the nutrients consumed by goat will be utilized by rumen microbes for growth. Rumen microbial growth will increase the microbial population in the rumen, and support increasing the process of fermentation in the rumen. Chanthakhoun et al. (2012) and Kang et al. (2012) stated that increasing dietary crude protein will increase rumen fermentation. Increased fermentation in the rumen was shown from the rumen VFA concentration, i.e. T1, T2 and T3 being 36.11, 39.41, $38.33 \mathrm{mMol}$, respectively. This was in agreement with the results of Wang (2012), Chanthakhoun et al. (2012) and Abubakr (2013b), that increasing fermentation increased VFA concentration, feed digestibility and feed efficiency, which in turn increase the amount of nutrients that can be utilized by animal for production. This was also coincide with the statement of Jia et al. (1995) that increment of DM digestibility increases LWG and feed efficiency. Therefore, increasing $\mathrm{CP}$ and TDN content in the diet increases LWG.

The experiment of Dutta et al. (2009) on 32 Barbari goats, fed different levels protein and level TDN, showed that CP 12\% and TDN 60\% was the optimum balance of protein and TDN for goats and feed efficiency (7.55\%). A similar result was reported by Agnihotri et al. (2006), that the appropriate CP and TDN to Barbari goats was 12 and $60 \%$. Similar study by Prieto et al. (2000) showed that the best $\mathrm{CP}$ and TDN for Boer $\mathrm{x}$ Spanish goats was 14.2 and $71.5 \%$, feed efficiency was $10.38-13.51 \%$. In the present experiment, the best $\mathrm{CP}$ and TDN ratio of feed was 11.67 and $58.61 \%$. As it is described above, increasing $\mathrm{CP}$ and TDN content in the diet affects feed efficiency. In this research feed efficiency was significantly different $(\mathrm{P}<0.05)$. Increasing $\mathrm{CP}$ and TDN content in the diet affect rumen fermentation, increasing rumen fermentation, increasing feed digestibility and increasing feed that can be utilized by goat. Increasing feed utilization, increased feed efficiency (Wang, 2012; Chanthakhoun et al., 2012; Abubakr, 2013a). 


\section{Body Composition on Kacang Goat}

The changes of body protein and fat of Kacang goats are presented at Table 3 . The body protein, body fat gain increased with dietary $\mathrm{CP}$ and TDN content. This was so due to the increased in feed efficiency (see Table 2). Improved feed efficiency indicates that more nutrients can be utilized for animal productivity and growth. Increased productivity and growth are shown at final BW (Table 3). Refer to Fox and Black (1984), Owens et al. (1993), Sanon et al. (2008) that goats with high growth rate tend to have higher BW, increasing BW increased body protein and body fat.

There was no significant difference $(\mathrm{P}>0.05)$ in body protein gain (\% and $\mathrm{kg}$ ) and body fat gain $(\mathrm{kg})$ among the treatments. Body protein gain on percentage and $\mathrm{kg}$ in average were $1.13 \%$ and $0.27 \mathrm{~kg}$ respectively, body fat gain $(\mathrm{kg})$ was 0.29 $\mathrm{kg}$. However, the percentage of body fat gain was significantly different $(\mathrm{P}<0.05)$ among the treatments. Body fat gain (\%) in T2 and were T3 higher than $\mathrm{T} 1(\mathrm{P}<0.05)$, but $\mathrm{T} 2$ and $\mathrm{T} 3$ were not significantly different $(\mathrm{P}>0.05)$. Fox and Black (1984), Schmidely et al. (1992) claimed that the growth of body protein on animals are relatively constant, and the growth of body fat inversely related to body water. In addition, body weight of goats in this research was not significantly different $(\mathrm{P}>0.05)$ so that body protein in this research was not different. This was in accordance with the results of Owens et al. (1993) that body weight affects body composition on animals. Changes in body fat in this study was different in percentage, but was not different in weight $(\mathrm{g})$. This was due to the body weight of goats among treatments. This was in accordance with the opinion of Owens et al. (1993), and Schmidely et al. (1992) that body weight affects the proportion of body fat.

The growth of body protein $(\%, \mathrm{~kg})$ and body fat growth $(\mathrm{kg})$ was not significantly different $(\mathrm{P}>0.05)$ among the treatments, because the animals used in this study had similar age, so they was at the same growth phase. This is in accordance with Purnomoadi et al. (2008) and D'Alessandro et al. (2013), that the growth of body protein in animal at various ages was relatively constant. In addition, the protein intake used by the animal to form the body weight was the same relatively, so that the body protein gain in this research was not significant differences.

Table 3. The change of Body Composition of Kacang goat during 8 Weeks Experiment

\begin{tabular}{lccc}
\hline \multicolumn{1}{c}{ Parameter } & $\mathrm{T} 1$ & $\mathrm{~T} 2$ & $\mathrm{~T} 3$ \\
\hline Body Weight (BW) (kg) & & & 15.6 \\
Preliminary & 15.57 & 15.30 & 18.95 \\
Final & 16.98 & 18.52 & \\
Intake (g/d) & & & $113.11^{\mathrm{C}}$ \\
Protein 0-8 weeks & $48.16^{\mathrm{A}}$ & $71.82^{\mathrm{B}}$ & $402.53^{\mathrm{b}}$ \\
TDN 0-8 weeks & $286.17^{\mathrm{a}}$ & $360.72^{\mathrm{b}}$ & \\
Nutrient Efficiency (\%) & & & 33.46 \\
Body protein gain & 43.00 & 35.61 & 13.61 \\
Body fat gain & 10.36 & 10.67 & 1.12 \\
Body Composition Gain 0-8 ${ }^{\text {th }}$ weeks & & & 0.26 \\
Body protein gain (\%/d) & 0.66 & 0.70 & $0.24^{\mathrm{b}}$ \\
Body protein gain (kg/d) & 0.14 & 0.19 & 0.37 \\
Body fat gain (\%/d) & $0.12^{\mathrm{a}}$ & $0.25^{\mathrm{b}}$ & 0.28 \\
Body fat gain (kg/d) & 0.20 & & \\
\hline
\end{tabular}

BW (Body Weight), ns = Non Significant $(\mathrm{P}>0.05)$, Superscript with different small letters in the same row indicate significant differences $(\mathrm{P}<0.05)$ 


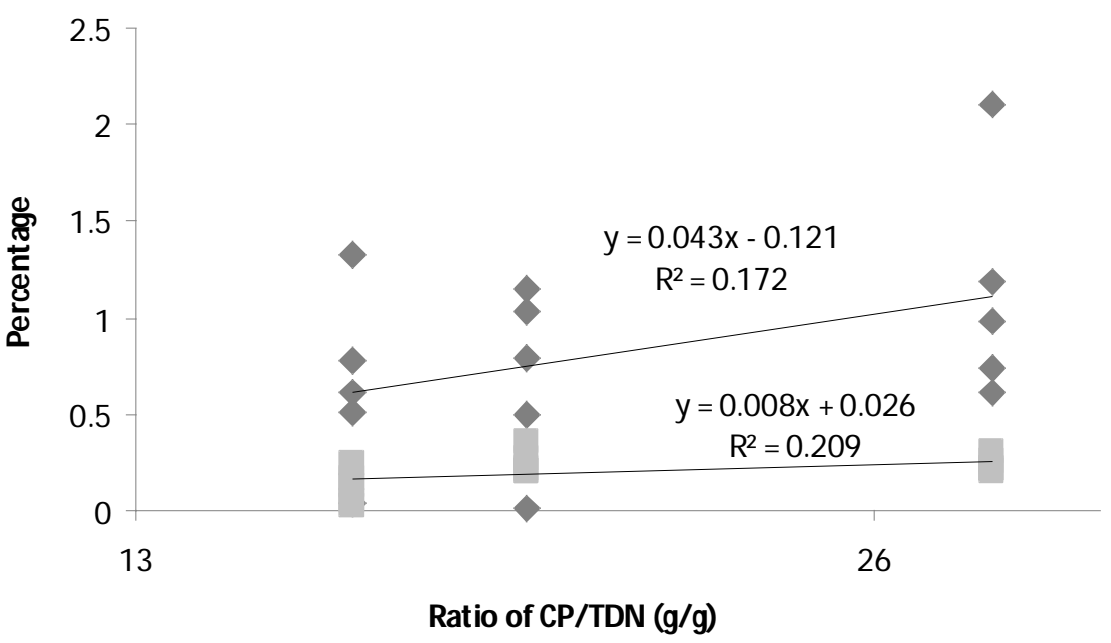

Figure 1. Relationship between CP/TDN Ratio of the Diets and Percentage of Body Protein $(\diamond)$ and Body Fat Gain (

Moreover, the efficiency of body protein and body fat in each treatment was not significantly different $(\mathrm{P}>0.05)$. This showed that the animals have the same ability to utilize the feed to form body protein and body fat.

\section{Relationship between increasing CP and TDN to Body Protein and Body Fat Gain}

Figure 1 shows that increasing $\mathrm{CP}$ and TDN was not significantly affect body protein gain and body fat gain. The results (Figure 2.) It was caused the animals used in this study have similar age, so it was the same growth phase. This was accordance with Owens et al. (1993), Purnomoadi et al. (2008), Alessandro et al. (2013), and Hassan and El-Feel (1991) that growth phase grouped by age and age affect the growth phase. In addition, weak correlation was also caused by nutritional efficiency of goat that were not significantly different, this case illustrated that the goat feed that can be utilized for growth was not significantly different. This was in accordance with Lancaster et al. (2009) who stated that feed efficiency used for productivity and for growth. Correlation between the $\mathrm{CP}$ and TDN to body fat gain was greater than the correlation between $\mathrm{CP}$ and TDN to body protein gain. This was caused the body protein gain in goat is relatively constant, while the body fat will continue to rise (Fox and Black, 1984; Schmidely et al., 1992; Purnomoadi et al., 2008).

The relationship between increasing $\mathrm{CP}$ and
TDN to body protein and body fat gain is shown at Ilustration 1. Increasing CP and TDN was not significantly correlated with body protein gain $(\mathrm{r}$ $=1.81, \mathrm{P}>0.05)$, and body fat gain $(\mathrm{r}=2.09$, $\mathrm{P}>0.05$ ), which means that the increase in the $\mathrm{CP}$ and TDN was not lead to increase body protein and body fat gain. This is because the nutrients were used in equal amounts by animals. So that the resulting growth was in the same value. It was also shown from nutrient efficiency of each diets were not significantly different.

\section{CONCLUSION}

Based on the result of this study, it can be concluded that the higher quality diet results in higher productivity, but did not affect body composition of Kacang goat, except body fat gain.

\section{REFERENCES}

Abdullah, A. Y. and H. S. Musallam. 2007. Effect of different levels of energy on carcass composition and meat quality of male black goats kids. Livestock Sci. 107: 70-80.

Abubakr, A.R., A.R. Alimon, H. Yaakub, N. Abdullah, and M. Ivan. 2013a. Growth, nitrogen metabolism and carcass composition of goats fed palm oil byproducts. Small Rum. Res. 112: 91- 96.

Abubakr, A.R., A.R. Alimon, H. Yaakub, N. Abdullah, and M. Ivan. 2013. Digestibility, rumen protozoa, and ruminal fermentation 
in goats receiving dietary palm oil byproducts. Journal of the Saudi Society of Agricultural Sciences 12: 147-154.

Agnihotri, M. K., V. Rajkumar and T. K. Dutta. 2006. Effect of feeding complete rations with variable protein and energy levels prepared using by-products of pulses and oilseeds on carcass characteristics, meat and meat ball quality of goats. J. Anim. Sci. 19 (10): 1437 - 1449.

Aregheore, E. M. 2006. Utilization of concentrate supplements containing varying levels of copra cake (Cocos nucifera) by growing goats fed a basal diet of napier grass (Pennisetum purpureum). Small Rum. Res. 64: 87-93.

Astuti D. A. and D. Sastradipradja. 1999. Evaluation of body composition using urea dilution and slaughter technique of growing Priangan sheep. Media Veteriner. 6 (3): 5-9.

Atti, N., H. Rouissi, and M. Mahouachi. 2004. The effect of dietary crude protein level on growth, carcass and meat composition of male goat kids in Tunisia. Small Rum. Res. 54: 89-97.

Bartle, S. J., J. R. Males and R. L. Preston. 1983. Evaluation of urea dilution as an estimator of body composition in mature cows. J. Anim. Sci. 56 (2): 410-417.

Boorman, K. N. 1980. Dietary Contain on Nitrogen Retention. Dalam: P. J. Buttery dan D. B. Linsay (Editor). Protein Deposition in Animal. 1st Ed. Butterworths, London. p 145-165.

Chanthakhoun, V., M. Wanapat, and J. Berg. 2012. Level of crude protein in concentrate supplements influenced rumen characteristics, microbial protein synthesis and digestibility in swamp buffaloes (Bubalus bubalis). Livestock Sci. 144: 197204.

D’Alessandroa, A. G., G. Maiorano, M. Ragni,D. Casamassima, G. Marsico and G. Martemucci. 2013. Effects of age and season of slaughter on meat production oflight lambs: Carcass characteristics and meat quality of Leccese breed. Small Rum. Res. 114: 97-104.

Dinas Peternakan Brebes dan Balai Pengkajian Teknologi Pertanian Jawa Tengah. 2005. Inventarisasi Sumberdaya Hayati Ternak Lokal Jawa Tengah. Dinas Peternakan Brebes Kerjasama dengan Balai Pengkajian Teknologi Pertanian Jawa Tengah. Ungaran.
Direktorat Jendral Peternakan dan Kesehatan Hewan. 2012. Statistik Peternakan. Direktorat Jenderal Peternakan dan Kesehatan Hewan, Kementerian Pertanian. p 10.

Dutta, T. K., M. K. Agnihotri, P. K. Sahoo, V. Rajkumar, and A. K. Das. 2009. Effect of different protein-energy ratio in pulse byproducts and residue based pelleted feeds on growth, rumen fermentation, carcass and sausage quality in Barbari kids. Small Rum. Res. 85: 34-41.

Fox, D. G. and J. R. Black. 1984. A System For Predicting Body Composition and Performance of Growing Cattle. J. Anim. Sci. 58 (3) : 725-735.

Gatenby, R. M. 1988. Goat husbandry in West Timor, Indonesia. Small Rum. Res. 1:113121.

Hassan, H.A., and F.M.R. El-Feel. 1991. The effect of breed, level of feeding, age and slaughter weight on performance and carcass traits of lambs. Egyptian Journal of Animal Production, 28(2):225-168.

Jia, Z. H., T. Sahlu, J. M. Fernandez, S.P. Hart, and T.H. The. 1995. Effects of dietary protein level on performance of Angora and cashmere-producing Spanish goats. Small Rum. Res. 16:113-119.

Kang, S., M. Wanapat, P. Pakde, R. Pilajun, and A. Cherdthong. 2012. Effects of energy level and Leucaena leucocephala leaf meal as a protein source on rumen fermentation efficiency and digestibility in swamp buffalo. Anim. Feed Sci. Tech. 74:131- 139.

Karami, M., E.N. Ponnampalam, and D.L. Hopkins. 2013. The effect of palm oil or canola oil on feedlot performance, plasma and tissue fatty acid profile and meat quality in goats. Meat Sci. 4:165-169.

Kearl L. C. 1982. Nutrient Requirements of Ruminants In Developing Countries. International Feedstuffs Institute Utah Agricultural Experiment Station Utah State University, Logan Utah.

Lancaster, P. A., G. E. Carstens, F. R. B. Ribeiro, L. O. Tedeschi and D. H. Crews, Jr. 2009. Characterization of feed efficiency traits and relationships with feeding behavior and ultrasound carcass traits in growing bulls. J. Anim. Sci. 87:1528-1539.

Mahgoub, O., C. D. Lu, and R. J. Early. 2000. Effects of dietary energy density on feed intake, body weight gain and carcass 
chemical composition of Omani growing lambs. Small Rum. Res. 37: 35-42.

Manso. T., A. R. Manteco'n, F. J. Giraldez, P. Lav 'in, and T. Castro. 1998. Animal performance and chemical body composition of lambs fed diets with different protein supplements. Small Rum. Res. 29: 185-191.

Martawidjaja, B. Setiadi and S. S. Sitorus. 1999. pengaruh tingkat protein-energi ransum terhadap kinerja produksi kambing kacang muda. Jurnal Ilmu Ternak dan Veteriner. 4 (3):167-173

Ngwa, A.T., L. J. Dawson, R. Puchala, G. Detweiler, R. C. Merkel, I. Tovar-Luna, T. Sahlu, C. L. Ferrell, and A. L. Goetsch. 2007. Effect of initial body condition of Boer $\times$ Spanish yearling goat wethers and level of nutrient intake on body composition. Small Rum. Res. 73:13-26.

Owens, F. N., P. Dubeski, and C. F. Hanson. 1993. Factors that alter the growth and development of ruminants. J. Anim. Sci. 71:3138-3150.

Panaretto, B. A. and A. R. Till. 1963. Body composition in vivo (II). Aust. J. Agric. Res. 14: 926-943.

Prieto, I., A. L. Goetsch, V. Banskalieva, M. Cameron, R. Puchala, T. Sahlu, L. J. Dawson and S. W. Coleman. 2000. Effects of dietary protein concentration on postweaning growth of Boer crossbred and Spanish goat wethers. J. Anim. Sci. 78:2275-2281.

Purnomoadi, A., B. M. Alviani, E. Rianto, E. Purbowati, and Soeparno. 2008. Body composition of ongole crossbred growing bull under intensive feeding management. J. Indon. Trop. Anim. Agric. 33 (4):262-267.

Rule, D. C., R. N. Arnold, E. J. Hentges and D. C. Beitz. 1986. Evaluation of urea dilution as a technique for estimating body composition of beef steers in vivo: validation of published equations and comparison with chemical composition. J. Anim. Sci. 63:1935-1948.
Sahlu, T., S. P. Hart, and A. L. Goetsch. 1999. Effects of level of feed intake on body weight, body components, and mohair growth in Angora goats during realimentation. Small Rum. Res. 32:251259.

Sanon, H. O, C. Kaboré-Zoungrana, and I. Ledin. 2008. Growth and carcass characteristics of male Sahelian goats fed leaves or pods of Pterocarpus lucens or Acacia Senegal. Livestock Science 117:192-202.

Schmidely, P., P. Bas, A. Rouzeau, J. Hervieu and P. Morand-Fehr. 1992. Influence of trenbolone acetate combined with estradiol17 beta on growth performance, body characteristics, and chemical composition of goat kids fed milk and slaughtered at different ages. J. Anim. Sci. 70: 3381-3390.

Soeparno. 1992. Ilmu dan Teknologi Daging. Gadjah Mada University Press. Yogyakarta.

Sumardianto, T. A. P., Endang Purbowati and Masykuri. 2013. Karakteristik karkas kambing kacang, kambing peranakan ettawa, dan kambing kejobong jantan pada umur satu tahun. J. Anim. Agric. 2(1):175182.

Triyantini, R. Sunarlim, H. Setiyanto, B. Setiadi and M. Martawidjaja. 2002. Kajian tentang perbandingan karakteristik komponen karkas kambing Kacang dan silangannya (Boer X Kacang) pada kondisi pakan berbeda. Pros. Seminar Nasional Teknologi Peterrnakan dan Veteriner. Puslitbang Peternakan, Bogor. p 165-169.

Usmiati, S. and H. Setiyanto. 2008. Penampilan karkas dan komponen karkas ternak ruminansia kecil. Pros. Seminar Nasional Teknologi Peterrnakan dan Veteriner. Puslitbang Peternakan, Bogor. p 371-379.

Wang, C., Q. Liu, C. X. Pei, H.Y. Li, Y. X. Wang, H. Wang, Y. S. Bai, Z. G. Shi, X. N. Liu, and P. Li. 2012. Effects of 2-methylbutyrate on rumen fermentation, ruminal enzyme activities, urinary excretion of purine derivatives and feed digestibility in steers. Livestock Science 145: 160-166. 